\title{
Prevalence of Risk Factors for Breast Neoplasm in the City of Maringá, Paraná State, Brazil ${ }^{1}$
}

\author{
Jéssica Carvalho de Matos ${ }^{2}$ \\ Sandra Marisa Pelloso ${ }^{3}$ \\ Maria Dalva de Barros Carvalho ${ }^{4}$
}

The aim of this study was to identify the prevalence of the risk factors for breast cancer among women between 40 and 69 years old in the city of Maringá, Paraná State, Brazil. An analytical, exploratory and cross-sectional study was carried out through a population research at homes in Maringá. The sample was composed of 439 women between 40 and 69 years old. The data were collected by home interviews, stored using the Statistical Package for the Social Sciences (SPSS) software and presented in tables as absolute and relative frequency. The predominant ethnical group was Caucasian with an average age of 52 years. Among risk factors identified in the present study, an expressive number of overweight women were found. It is important and necessary to put in practice actions that identify the modifiable risk factors for the development of breast tumors in order to reduce morbidity and mortality levels due to this pathology.

Descriptors: Breast Neoplasms; Risk Factors; Prevalence.

\footnotetext{
${ }_{1}^{1}$ Paper extracted from Master's Thesis "Prevalência e fatores associados à prevenção secundária do câncer de mama em Maringá - PR" presented to Universidade Estadual de Maringa (UEM), Maringá, PR, Brasil.

${ }^{2}$ RN, Master's Dissertation, Faculty, Faculdade Ingá (UNINGÁ), PR, Brazil. E-mail: jessicamaringa@yahoo.com.br.

${ }^{3}$ RN, Ph.D. in Nursing, Faculty, Universidade Estadual de Maringá, PR, Brazil. E-mail: smpelloso@uem.br.

${ }^{4}$ RN, Ph.D. in Nursing, Faculty, Universidade Estadual de Maringá, PR, Brazil. E-mail: mdbcarvalho@uem.br.
}

Corresponding Author:

Jéssica Carvalho de Matos UNINGÁ - Faculdade Ingá Av. Colombo, 9727 Km 130 CEP: 87070-810 Maringá, PR, Brasil E-mail: jessicamaringa@yahoo.com.br 


\title{
Prevalência de fatores de risco para o câncer de mama no município de Maringá, Paraná, Brasil
}

Esse estudo pretendeu identificar a prevalência dos fatores de risco para o câncer de mama em mulheres de 40 a 69 anos, no município de Maringá. Foi realizado estudo analítico, exploratório, de corte transversal, tipo inquérito populacional domiciliar. 0 estudo foi realizado com 439 mulheres entre 40 e 69 anos. Os dados foram coletados por entrevistas domiciliares, armazenados no programa Statisitical Package for the Social Sciences (SPSS) e apresentados em forma de frequência absoluta e relativa. A maior parte das mulheres estudadas pertence à raça branca, com média de idade de 52 anos. Dentre os fatores de risco identificados destaca-se o grande número de mulheres acima do peso. Ressalta-se a importância da implementação de ações que visem a identificação dos fatores de risco modificáveis para o desenvolvimento do câncer de mama para, com isso, diminuir o número de adoecimento e morte por essa patologia.

Descritores: Neoplasias da Mama; Fatores de Risco; Prevalência.

\section{Prevalencia de factores de riesgo para el cáncer de mama en el municipio de Maringá, en el estado de Paraná, Brasil}

\begin{abstract}
Ese estudio pretendió identificar la prevalencia de los factores de riesgo para el cáncer de mama en mujeres de 40 la 69 años, en el municipio de Maringá. Fue realizado un estudio analítico, exploratorio, de corte transversal, tipo encuesta poblacional domiciliar. E estudio fue realizado con 439 mujeres entre 40 y 69 años. Los datos fueron recolectados durante entrevistas domiciliares, almacenados en el programa Statisitical Package for the Social Sciences (SPSS) y presentados en forma de frecuencia absoluta y relativa. La mayor parte de las mujeres estudiadas pertenecía a la raza blanca, con promedio de edad de 52 años. Entre los factores de riesgo identificados se destaca el gran número de mujeres con sobrepeso. Se resalta la importancia de la implementación de acciones que tengan por objetivo identificar los factores de riesgo modificables para el desarrollo del cáncer de mama para, con eso, disminuir el número de nuevos casos y de muerte por esa patología.
\end{abstract}

Descriptores: Neoplasias de la Mama; Factores de Riesgo; Prevalencia.

\section{Introduction}

Changes in the population's lifestyle, particularly the adoption of unhealthy life habits, significantly affect the increase in cancer cases in the global population. Of all cancer types, breast tumors stand out among women, as observed by the frightening statistics.

Estimates for 2008 in Brazil, valid for 2009 as well, indicate 466,730 new cases of cancer and one of the most incident types among women is breast cancer, with an estimated number of 49,400 new cases $(50.71 / 100,000$ women). Breast tumors are the most frequent type of cancer among women in the South of Brazil, totaling an estimated risk of $67 / 100,000$ women. In Paraná, 2970 new cases of breast cancer (56.7/100,000 women) occurred in 2006. In 2008, estimates previewed 56.16 cases for every 100,000 women ${ }^{(1-2)}$.

Until date, breast cancer cannot be avoided, but some risk factors of the disease have already been discovered, which can facilitate early detection and contribute to cancer screening(3). The most discussed risk factors are the woman's age and family history, that is, having a first-degree relative with breast cancer ${ }^{(4)}$. The age range between 40 and 69 years stands out with the highest prevalence levels of illness and death by this type of cancer(5).

As well-established risk factors for the development of risk factors, the Ministry of Health 
defines those related to the woman's reproductive life (early menarch, before the age of 11 years; nulliparity; first pregnancy after the age of 30 ; use of oral contraceptives; later menopause, after the age of 50 , and use of hormone replacement therapy). The age factor is still one of the most important risk factors though. Incidence levels of breast cancer increase rapidly until the age of 50 , after which the increase continues at a slower pace(1).

In scientific terms, there are no specific strategies that permit primary breast cancer prevention, although its incidence can be decreased through health promotion actions, emphasizing attention with risk factors, including obesity and smoking ${ }^{(5)}$.

In view of this problem, this research intended to identify the prevalence of risk factors for breast cancer in women between 40 and 69 years, in Maringá, PR.

\section{Material and Methods}

To reach the proposed objective, an analytic, exploratory, cross-sectional population research was carried out at homes in Maringá, PR.

The study involved a sample of women between 40 and 69 years old. This age range was chosen due to the greater prevalence of illness and death by breast cancer in the age range between 40 and 69 years $^{(5)}$.

The sample comprised 439 women (using a $95 \%$ confidence interval and adding $14 \%$ for possible losses). Randomly stratified sampling was used, geographically dividing the entire Maringá region in five strata: North, South, East, West and Center. Then, the sectors that participated in each stratum were randomly selected according to the demographic density of each. From each stratum, a simple random sample was selected, proportional to the number of women living in each of these strata.

Data were collected through home interviews, which the researchers held with the help of a structured and pretested interview form, containing questions about socioeconomic, biological, behavioral and service use questions. Then, they were stored in a Statistical Package for the Social Sciences (SPSS) worksheet, version 15.0, and presented as absolute and relative frequencies in tables.

The variables used in this research, according to the Ministry of Health, were: age between 40 and 69 years $^{(5)}$, Caucasian race, obesity, alcohol consumption, smoking, nulliparity, first pregnancy after the age of 30 years, early menarch (before the age of 11 years), late menopause (after the age of 50 years), mother or sister with history of breast cancer, personal history of breast cancer(6), prolonged use of oral contraceptives and use of hormone replacement therapy ${ }^{(1)}$.

Approval for the project was obtained from the Institutional Review Board at Universidade Estadual de Maringá (Opinion n.406/2007).

\section{Results}

The profile of the study population comprised 439 women between 40 and 69 years, with a mean age of 53 years. The prevalent race was Caucasian, with $81.1 \%$ of women. A large number of interviewed women were classified as overweight (38.7\%) and a significant number as obese $(24.1 \%)$ (Table 1 ).

Table 1 - Percentage distribution of interviewees according to body mass index. Maringá, PR, 2008

\begin{tabular}{lcc}
\hline \multicolumn{1}{c}{ Classification* $^{*}$} & N & $\%$ \\
\hline Underweight & 12 & 2.7 \\
Normal weight & 151 & 34.4 \\
Overweight & 170 & 38.7 \\
Obese & 106 & 24.1 \\
\hline
\end{tabular}

*Variable based on the Brazilian Association for the Study of Obesity and the Metabolic Syndrome, $2008^{(7)}$.

Among the interviewed women, $76.1 \%$ (334) reported they had never consumed alcoholic beverages and $21.2 \%$ (93) mentioned social drinking. Only four women mentioned using alcoholic beverages more frequently (weekly or daily). Only $13 \%$ (57) of the women mentioned smoking, while $20 \%$ (88) had smoked in the past. Sixty-two percent of the interviewees had already used oral contraceptives, with a mean usage time of 4.68 years (sd: 5.81 ).

In the study group, only $6.8 \%$ (30) had never been pregnant and, among women who had been pregnant at least once, in $38.7 \%$ of cases, they had their first child between 16 and 20 years of age, with a mean age of 20.47 years (sd: 7.7). Among women who had already been pregnant, $82.7 \%$ had breastfed, $33.9 \%$ between 1 and 12 months, with a mean of 32 months (sd: 46.6).

The mean age of the menarch was 13 years (sd: 2.37), against 47 years for the menopause (sd: 6.28). Thirty-six percent $36 \%$ (158) of the interviewees had not entered the menopause yet at the time of the interview (Table 2). 
Table 2 - Percentage distribution of interviewees according to age of menarch and menopause. Maringá, PR, 2008

\begin{tabular}{lcc}
\multicolumn{1}{c}{ Variable } & N & $\%$ \\
\hline Age of menarch & 8 & 1.8 \\
Does not remember & 162 & 36.9 \\
9 to 12 years & 234 & 53.3 \\
13 to 15 years & 35 & 8 \\
16 to 18 years & & \\
Age of menopause & 158 & 36 \\
Has not stopped yet & 2 & 0.5 \\
Does not remember & 4 & 0.9 \\
24 to 31 years & 31 & 7.1 \\
32 to 39 years & 88 & 20 \\
40 to 47 years & 140 & 31.9 \\
48 to 55 years & 16 & 3.6 \\
56 to 63 years & & \\
\hline
\end{tabular}

As for the family history of breast cancer, $2.3 \%$ (10) of the women reported that their mother has or had breast cancer. When the question asked was about "having a daughter who has or had breast cancer", the percentage was $0.2 \%(1)$, against $3.9 \%$ (17) for a sister. Only $8 \%$ (35) of the women reported another relative, without first-degree kinship, who has or had breast cancer (Table 3).

Table 3 - Percentage distribution of interviewees according to family history of breast cancer, considering the degree of kinship. Maringá, PR, 2008

\begin{tabular}{cccccccc}
\hline \multicolumn{4}{c}{ Family member who has or had breast cancer } \\
\multicolumn{3}{c}{ Mother } & \multicolumn{2}{c}{ Sister } & \multicolumn{2}{c}{ Daughter } & \multicolumn{2}{c}{ Other relative } \\
\hline N & $\%$ & N & $\%$ & N & $\%$ & N & $\%$ \\
10 & 2.3 & 17 & 3.9 & 1 & 0.2 & 35 & 8 \\
\hline
\end{tabular}

It is highlighted that $2.3 \%$ (10) of the interviewees already had a benign breast disease and that only $0.9 \%$ (4) had a personal history of breast cancer, $75 \%$ (3) of whom reported they had discovered the cancer through the breast self-exam and $25 \%$ (1) through a mammography. In the study group, $7.1 \%$ (31) had already been subject to a biopsy or breast surgery (disregarding plastic or esthetic surgeries), 19.4\% (5) of whom reported a malign result of the biopsy. As for the use of hormone replacement therapy, 69.2\% (305) had never used his treatment and, among women who had, the mean usage time was 5.2 years (sd: 5.3 ) (Table 4 ).
Table 4 - Percentage distribution of interviewees according to use of hormone replacement therapy, considering usage time. Maringá, PR, 2008

\begin{tabular}{lcc}
\multicolumn{1}{c}{ Variable } & N & $\%$ \\
\hline Hormone replacement therapy & 305 & 69.2 \\
No, has never taken & 48 & 10.9 \\
Yes, is taking & 86 & 19.6 \\
Took in the past & & \\
Usage time & 305 & 69.2 \\
No treatment & 6 & 1.4 \\
Less than 1 year & 90 & 20.5 \\
1 to 6 years & 24 & 5.5 \\
7 to 13 years & 14 & 3.2 \\
14 to 23 years & & \\
\hline
\end{tabular}

\section{Discussion}

The interviewed women's mean age was 53 years and the large majority was Caucasian (81.1\%). Very similar characteristics were observed in a populationbased study of women between 40 and 69 years, carried out in Pelotas in 2002, where the studied women's mean age was 52.1 years and a majority was white $(80 \%)^{(8)}$. In another study of women undergoing breast cancer treatment, the Caucasian race also predominated $(80 \%)$, with an average age of 54 years $^{(9)}$.

Advanced age, generally 50 years or more, is reported to be the most important causal factor of breast cancer and, in most cases, the only factor ${ }^{(10)}$. Consequently, mortality rates increase in this age range, mainly due to the fact that the diagnosis is mostly reached in advanced stages of the disease.

Another study reports the Caucasian race as a risk factor for the development of breast cancer, besides the woman's advanced age(3).

As for the risk factors alcohol consumption and smoking, most of the interviewees $(76,1 \%)$ reported no alcohol use and $87 \%$ mentioned no current smoking. These findings are similar to the results found in another research, also carried out in Maringá in 2006, involving women of reproductive age, in which $59.9 \%$ of the women did not use alcohol and $77.7 \%$ mentioned no tobacco use ${ }^{(11)}$. The present research data reveal higher prevalence levels for healthy habits, which may suggest that, at a more advanced age, in this case between 40 and 69 years, women are more concerned with their health and modify their lifestyle. A study carried out in Cuiabá in 2004 and 2005 though, found that 63.15\% of the studied women who underwent mastectomy had never smoked(3). 
It was concluded that tobacco use increases the incidence of breast tumors in women with a family history that shows multiple cases of breast or ovarian cancer. This fact is even more noteworthy in case of predisposition to associated factors ${ }^{(12)}$.

Smoking is a risk factor for breast cancer and various other types of cancer, and also increases the probability of developing pulmonary and cardiovascular diseases. As for alcoholic consumption, the use of alcoholic beverages is also associated with a proportional increase in the development of breast cancer, that is, the more one drinks, the greater the chance that this cancer will appear(13).

As for the use of hormone replacement therapy, in this research, it was found that $69.2 \%$ (305) of the women who never did this treatment, $10.9 \%$ (48) were taking the treatment at the time of the interview and $19.6 \%$ (86) had taken it for some time but had already stopped. The mean usage time of hormone replacement therapy was 5.2 years (sd: 5.3). In another study of women who underwent mastectomy, it was identified that $84.21 \%$ were in the menopause, $81.25 \%$ were not taking hormone replacement, while $18.75 \% \mathrm{did}^{(3)}$.

Estrogen, one of the hormones used in hormone replacement therapy, plays an important role in the development of breast cancer, as it induces the growth of breast tissue cells ${ }^{(14)}$. In the study population, however, only a small part of the women (10.9\%) use hormone replacement therapy.

These study results revealed that almost all women had already been pregnant and had their first child at the mean age of 20.47 years. Low prevalence rates were found for having one's first child at advanced age, over 30 years.

A late first pregnancy constitutes one of the nonmodifiable risk factors that increase the risk of breast cancer ${ }^{(15)}$. Nulliparity or a small number of pregnancies is a tendency associated with current socioeconomic development and, in many studies, represents an important factor for the development of breast cancer.

A case-control study of 156 women in Juiz de Fora, MG, revealed that having had four or more children represents a protection factor for breast cancer, and living in the rural area is associated with greater risk for the development of this disease ${ }^{(16)}$.

Among the interviewed women who had already been pregnant, $82.7 \%$ breastfed, $33.9 \%$ between 1 and 12 months. A case-control study in the South of Brazil found that breastfeeding did not protect against breast cancer ${ }^{(17)}$, although literature reports that it can contribute to the decreased incidence of this cancer. Another study, however, defends that high parity and breastfeeding are possible protection factors against the appearance of breast cancer ${ }^{(16)}$.

Among the studied women, $62 \%$ use or had used oral contraceptives, with a mean usage time of 4.7 years. It is interesting to highlight that, in a research carried out in 2004, aimed at assessing care quality and reproductive health conditions among women who used public health services in Maringá, appointed that among currently used contraception methods, those classified as the pill prevailed in 50.3\%, tubal ligation $32 \%$ and condom $28.1 \%{ }^{(11)}$. This difference in the obtained data can be related to the age range under analysis as, in the present research, the selected age range was between 40 and 69 years.

The results of a study among women between 20 and 60 years old who lived in the South of Rio Grande do Sul between 1995 and 1998 appoint no association between the use of oral contraceptives and breast cancer, neither for different usage times nor start ages. Increased risk levels were also evidenced in the subgroup of women who had used oral contraceptives for more than five years and women over 45 years of age, although without a statistically significant difference ${ }^{(18)}$.

Nowadays, contraceptives contain low doses of estrogen, thus resulting in a lower risk potential for the development of breast cancer. When the use of contraceptives is associated with other factors though, including smoking, obesity, among others, the chances of developing this cancer increase ${ }^{(15)}$.

With regards to the family history of breast cancer, in the female population under analysis, it was evidenced that only $2.3 \%$ have a mother who has or had breast cancer, $3.9 \%$ a sister and $0.2 \%$ a daughter, and this percentage increases to $8 \%$ in case of having another relative with breast cancer.

In a study carried out in Rio Grande do Sul in 2005, a prevalence level of $5.6 \%$ of family history of breast cancer was found and, when considering relatives beyond the first degree, prevalence rates increased to $10.2 \%{ }^{(8)}$. Similar findings appeared in a study where $5.26 \%$ of the interviewed women had some relative (mother, sister or daughter) with breast cancer(3). In both studies, a small number of women had some first-degree relatives with breast cancer, like in the present research.

Among women with a first-degree family history of breast cancer who live in places with high incidence levels, the risk of developing breast cancer is $13.3 \%$ higher than in women without these characteristics ${ }^{(19)}$. 
This risk increases when the relative has breast cancer before the age of 50 years and in both breasts(15).

One of the most concerning data found in this research was the interviewees' body mass index (BMI), as $38.7 \%$ were overweight and $24.1 \%$ were classified as obese.

Obesity during post-menopause is considered a risk factor for the development of breast cancer. Other studies, though, defend that obesity is considered a protective effect in the pre-menopause ${ }^{(15)}$.

A study among women with breast cancer in Maringá evidenced a large number of overweight women, with $32.53 \%$ of the interviewees being considered obese ${ }^{(20)}$. Fat tissue is considered a large steroid deposit and the enzymatic reaction responsible for converting androgens into estrogens occurs in men as well as women, turning obesity into a risk factor for the development of breast cancer, due to the fact that fat is estrogenic ${ }^{(21)}$.

Obesity, together with cigarette and alcohol use, refers to the lifestyle that can be modified, as it is also considered a risk factor for the development of other chronic-degenerative diseases.

In the present research, the mean age of the menarch was 13 years and the mean age for the menopause was 47 years.

A study on risk factors, carried out in Colombia in 2006, evidenced that, if the menarch occurs before the age of 11 years, the risk of breast cancer occurs between 10 and $12 \%$. With regard to the menopause, if it occurs at a later age (after 53 years), this risk is doubled(19).

Another study found that, in $47.4 \%$ of the women, the menarch occurred between 10 and 13 years of age, with a mean age of 13.31 years $^{(3)}$. Early menarch is reported as a risk factor due to exposure to estrogen. In women who start a regular cycle rapidly, the cumulative estrogen exposure rate increases, as the levels of this hormone are higher during the normal luteal phase ${ }^{(14)}$.

In this study, no significant levels were found for women with an early menarch or late menopause. Hence, these were not considered risk factors of concern for the development of breast cancer in this population.

Among the 439 women who were interviewed, only $0.9 \%$ (4) has a personal history of breast cancer, $75 \%$ (3) of whom reported the discovery through the breast self-exam (BSE) and 25\% (1) through the clinical breast exam (CBE). Among women who already had breast cancer at some point in their life, the chances of developing this type of cancer in the other breast increase $^{(13)}$.
In a study carried out in Maringá in 2006, among 50 women with breast cancer under analysis, a majority (76\%) had no antecedents of a benign breast disease. The same study reported that, among women who had done a biopsy, a majority of the interviewees (60\%) could inform the result. Twenty-four percent (12) of the interviewees discovered the breast cancer through the BSE, 20\% (10) during a medical consultation and a majority (56\%) in another way, including feeling pain, breast trauma and visualization ${ }^{(9)}$.

In the main risk factors for the development of breast cancer, including age, family history, reproductive history and genetic susceptibility, no intervention is possible, but smoking and obesity should be targets of primary intervention for breast cancer. Primary intervention for breast cancer aims to stimulate healthy life habits, which include not smoking, maintaining balanced meals, maintaining one's ideal weight and consuming alcoholic beverages moderately ${ }^{(15)}$.

Among educational measures, besides smoking and obesity, it should be highlighted that the use of hormone replacement therapy and contraceptives and even antibiotics use are considered probable risk factors for the development of breast cancer(22).

Different articles discuss the importance of studying the risk factors for breast cancer but, until today, research has not clearly elucidated the association between all risk factors found and the incidence of this cancer. It is known that incidence levels increase gradually, reflecting the global trend towards the predominance of lifestyles that strengthen exposure to risk factors ${ }^{(23)}$. Although the etiology of breast cancer is unknown and multicausal, the best way to control its evolution is by knowing its risk factors. Hence, early diagnosis remains the best form of protection ${ }^{(24-25)}$. Modifiable risk factors should be studied not only to avoid the emergence of breast cancer, but also serve to achieve a better quality of life. In other words, unhealthy life habits like smoking, consuming alcohol frequently, a sedentary life and obesity, among others, increase the probability not only of breast cancer, but also of other types of cancer and different other chronic-degenerative diseases.

\section{Conclusions}

Most women in this study were Caucasian, with a mean age of 53 years. Many $(76,1 \%)$ of them reported they had never consumed alcohol, and only $13 \%$ mentioned they smoked cigarettes. Most of the 
interviewees were classified as overweight and obese, totaling $62.8 \%$ of the women. The mean age when their menopause started was 47 years and their menarch 13 years. Only $6.8 \%$ (30) had never been pregnant and, among women who had, a large majority breastfed $(82.7 \%)$. A mere $2.3 \%$ (10) of the women reported that their mother has or had breast cancer and 3.9\% (17) mentioned they had a sister with breast cancer.

In this research, some concerning events were observed with regard to the risk factors for breast cancer, including the high incidence of overweight women between 40 and 69 years of age in Maringá.

All women, independently of the existence of risk factors, should have access to and be stimulated towards secondary breast cancer prevention - clinical breast exam, mammography and stimulation of BSE. According to the age range with the highest incidence levels of breast cancer, i.e. between 40 and 69 years, it is interesting to include these prevention actions in comprehensive women's health care.

The study of risk factors can permit the identification of modifiable factors that increase the incidence of breast cancer cases, highlighting women's lifestyle, including diet, obesity, sedentary life, cigarette and alcohol use. A healthy life, together with the offering of secondary breast cancer prevention, would avoid many diseases and deaths due to the late diagnosis of breast cancer.

\section{References}

1. Ministério da Saúde (BR). Secretaria de Atenção à Saúde. Instituto Nacional do Câncer (INCA). Incidência do câncer no Brasil: estimativa 2008. 2008 [Acesso em: 15 maio 2008]. Disponível em: http://www.inca.gov.br/estimativa/2008/index. asp?link=conteu-do_view. $a s p \& I D=2$.

2. Ministério da Saúde (BR). Secretaria de Atenção à Saúde. Instituto Nacional do Câncer (INCA). Estimativas da incidência e mortalidade por câncer no Brasil. 2006. [Acesso em: 14 jan 2007]. Disponível em: http://www.inca.gov.br/estimativas/2006.

3. Borghesan DH, Pelloso SM, Carvalho MDB. Câncer de mama e fatores associados. Ciênc Cuidado e Saúde. 2008;7 Suppl 1:112-30.

4. Pinho VFS, Coutinho ESF. Fatores de risco para câncer de mama: uma revisão sistemática de estudos com amostras de mulheres da população geral no Brasil. Cad Saúde Pública. 2005; 21(2):39-54.

5. Ministério da Saúde (BR). Secretaria de Atenção à Saúde. Instituto Nacional do Câncer (INCA). Programa Nacional de Controle do Câncer de Colo de Útero e de Mama: viva mulher. 2008. [Acesso em: 13 maio 2008]. Disponível em: http://www. inca.gov.br/conteudo_view.asp?id=140.

6. Ministério da Saúde (BR). Secretaria de Atenção à Saúde. Instituto Nacional do Câncer (INCA). Coordenação de Prevenção e Vigilância (CONPREV). Falando sobre o câncer de mama. Rio de Janeiro (RJ): INCA; 2002.

7. Associação Brasileira para o Estudo da Obesidade e da Síndrome Metabólica (ABESO). 2008. [Acesso em: 20 jun 2008]. Disponível em: http://www.abeso.org.br/.

8. Sclowitz ML, Menezes AMB, Gigante DP, Tessaro S. Condutas na prevenção secundária do câncer de mama e fatores associados. Rev Saúde Pública. 2005; 39(3):340-9.

9. Campana HCR. Perfil de mulheres com câncer de mama [dissertação de mestrado]. Maringá (PR): Universidade Estadual de Maringá; 2007.
10. Pinho VFS, Coutinho ESF. Variáveis associadas ao câncer de mama em usuárias de unidades básicas de saúde. Cad Saúde Pública. 2007; 23(5):1061-9.

11. Souza JMM. Avaliação da saúde reprodutiva das usuárias da rede pública de saúde do Município de Maringá - PR. [dissertação de mestrado]. Maringá (PR): Universidade Estadual de Maringá; 2006.

12. Figueira AC Filho. Fatores de risco no câncer de mama. Rev Latino-am Mastol. 2002; 3(2):124-32.

13. Pirhardt $C R$, Mercês NNA. Fatores de risco para o câncer de mama: nível de conhecimento dos acadêmicos de uma universidade. Rev Enferm UERJ. 2009;17(1):102-6.

14. Ministério da Saúde (BR). Secretaria de Atenção à Saúde. Instituto Nacional do Câncer (INCA). Fatores de risco para o câncer de mama. 2008. [Acesso em: 15 jul 2008]. Disponível em: http//www.inca. gov.br/fatorderisco/2008.

15. Thuler LC. Considerações sobre a prevenção do câncer de mama feminino. Rev Bras Cancerol. 2003;49(4):227-38.

16. Paiva CE. Fatores de risco para o câncer de mama em Juiz de Fora (MG): um estudo caso-controle. Rev Bras Cancerol. 2002;48(2):15-27.

17. Tessaro S, Beria JU, Tomasi E, Victora CG. Amamentação e câncer de mama: estudo de caso-controle no sul do Brasil. Cad Saúde Pública. 2003;19(6):1593-1601.

18. Tessaro S, Beria JU, Tomasi E, Barros AJD. Contraceptivos orais e câncer de mama: estudo de casos e controles. Rev Saúde Pública. 2001; 35(1):32-8.

19. Molina EC. Estilo de vida para prevenir el cáncer de mama. Hacia Promoción Salud. Caldas. 2006;11:11-9.

20. Safar AS. Estudo do painel imunohistoquímico (receptor de estrogênio, receptor de progesterona e oncogene HER-2) em mulheres obesas e não obesas pós-menopausa e com diagnóstico de câncer de mama. [dissertação de mestrado]. Maringá (PR): Universidade Estadual de Maringá; 2008. 
21. Lordelo RA, Mancini MC, Cercato C, Halpern A. Eixos hormonais na obesidade: causa ou efeito? Arq Bras Endocrinol Metab. 2007;51(1):34-41.

22. Moraes AB, Zanini RR, Turchiello MS, Riboldi J, Medeiros LR. Estudo da sobrevida de pacientes com câncer de mama atendidas no hospital da Universidade Federal de Santa Maria, Rio Grande do Sul, Brasil. Cad Saúde Pública. 2006;22(10):2219-28.

23. Peres RS, Santos MA. Câncer de mama, pobreza e saúde mental: resposta emocional à doença em mulheres de camadas populares. Rev. Latino-Am. Enfermagem. 2007;15(número especial): 786-91.

24 Davim RMB, Torres GV, Cabral MLN, Lima VM, Souza MA. Auto-exame de mama: conhecimento de usuárias atendidas no ambulatório de uma maternidade escola. Rev. Latino-Am. Enfermagem. 2003;11(1):21-7.

25 Tonani M, Carvalho EC. Risco de câncer e comportamentos preventivos: a persuasão como estratégia de intervenção. Rev. Latino-Am. Enfermagem. 2008;16(5):67-74.

Received: Mar. $17^{\text {th }} 2009$

Accepted: Mar. $3^{\text {rd }} 2010$ 